\title{
Assessing the Indonesian Banking Risk: A Comparative Study between Islamic and Conventional Banks
}

\section{Yona Friantina*}

Graduate student, Department of Islamic Finance \& Banking, Politeknik Negeri Bandung, Indonesia

Received 10 October 2018; accepted 3 January 2019

\begin{abstract}
Technological advances and deregulation have driven banks to capitalize their benefits into some diversification activities they choose in the financial industry. This paper investigates the relation between service activities and risk of Indonesian banking industry in the period of 2015-2017. This study employs Structural Equation Modeling (SEM) with path analysis and multiple group analysis of 12 Islamic banks and 38 conventional banks. This study reveals that the Islamic banks appear to have more variable service activities and more stable risk than the conventional banks. For Islamic banks, non- financing income has a negative significant impact on bank risk; while commission income and trading income have a positive significant impact. Further, other non-financing income has a positive impact on bank risk. In the conventional banks, non-interest income has a positive impact on bank risk; while commission income has a negative impact. In addition, trading income also has a negative impact, and other non-interest income has a positive impact. These results imply that the Islamic banks emphasize the importance of expanding new service activities to reduce the risk. In conventional banks, diversified activ:ities contribute to higher income volatility and debt level. Thus, they need to reduce the high cost of depositors which include savings, demand deposits, time deposits, and also interest costs of long-term debt as the sources of fund.
\end{abstract}

\section{KEYWORDS}

Indonesian

banking

Risk

Service activities

Islamic bank

Conventional

bank

\section{INTRODUCTION}

Financial industries have expanded various activities to mitigate risk and improve their overall performance. The existence of bank diversification will generate income such as from commission, provision, fee adm.inistration, profit from the trading transaction, and other incomes. The alternative sources of income play an important role to reduce the excessive dependence on collection and distribution activities, which are the main sources of income. The risk of services activities is smaller than the credit/financing. The income diversification probably has a relatively small value, but it is certain. The Islamic bank is revealed as non-financing income banks but the conventional bank is recognized as non-interest income one (Molyneux\& Yip,2013; Suhartanto, Muflih,Setiawan, \& Hadiati, 2018). 
The conventional views that diversification strategies as the cost-based income sources can reduce the bank risk (Moudud-Ul-Huq, Ashraf, Gupta, \& Zheng, 2018). Diversification increases bank income and reduces bank crises (Hamdi, Hakimi, \& Zaghdoudi, 2017). The effect of product diversification on bank risk is related to asset size (Hidayat, Kakinaka, \& Miyamoto, 2012). The impact of income diversification influences the risk of banks with large total assets and equities (Nguyen, Vo, \& Nguyen, 2015). In the context of non-traditional activities, conventional banks obtain relatively higher non-traditional income than Islamic banks (Alfarisi, 2015). Conventional banks also have lower fee-based service activities than Islamic banks (Hardianto \& Wulandari, 2016).

This paper aims to find out which business models that have the ability to diversify income between Islamic and conventional banks, whereas Islamic banks have limitations in channeling the funds. The effect of income diversification is very useful to reduce the risk in conventional and Islamic banks. Although many researchers have disputed this issue, no research has been conducted about the impact of service activities on risk in the category of Islamic banks and conventional banks in Indonesia yet. Several previous studies discuss the impact of income diversification on risk only in the context of conventional banks, and also the risk measure that will be used by the researcher is different from the previous studies. Therefore, the research on bank risk prediction of conventional and Islamic banks is needed to be examined.

\section{THEORETICAL FRAMEWORK AND HYPOTHESES}

\section{Risk and Service Activities}

Bank diversification gives cost advantage to operating leverage (Elsas, Hackethal, \& Holzhauser, 2010). Compared to lending activities, the service activities have a lower fixed cost in operating leverage and lower capital requirement in financial leverage. To increase the efficiency of resource allocation and banks' debt capacity, Landskroner, Ruthenberg, and Zaken (2005) propose that the diversification can be supported by the exploitation of bank-specific assets in variant markets. The source of debt and the level of equity are important elements to define the risk (Ng, Xie, \& Kumaraswamy, 2010). From the lenders perspective, they would tend to reduce the debt according to risk profile while the equity investors would require a higher debt to minimize their capital injections (De Marco \& Mangano, 2013). The higher risk is related to the higher level of debt and decreases the equity capital injections (De Marco \& Mangano, 2017).

The study of Alfarisi (2015) shows that conventional banks obtain non-traditional income which is relatively higher than Islamic banks. Meanwhile, Islamic banks have a small-sized asset that is unfavorable to compete with their conventional counterparts. A research conducted by Molyneux and Yip (2013) finds that conventional banks have a higher service activity than Islamic banks. Therefore, the following hypothesis is developed:

$\mathrm{H}_{1}$ : Islamic banks are different from conventional banks model

A research of Karanja (2012) shows that higher non-interest income is associated with lower risk. Similarly, Hamdi et al. (2017) show that diversification enhances bank income and reduces the potential of bank crises. In addition, non-interest income has a negative and significant 
correlation with risk. As mentioned in Trivedi (2015), the effect of non-interest income on risk is not statistically significant but beta values indicate that the effect of diversification is negative on risk. In contrast, studies such as Hamdi et al. (2017), Karanja (2012), and Trivedi (2015), Ekanayake and Wanamalie (2017) show that there is a positive correlation between non-interest income and risk. Being consistent with Ekanayake and Wanamalie (2017) as well as Nisar, Peng, Wang, and Ashraf (2018) show that non-interest income has a positive significant impact on risk. Lepetit, Nys., Rous, and Tarazi (2008) also find that the higher non-interest activities have a positive and significant for the large listed banks. This study develops the second hypothesis:

$\mathrm{H}_{2}$ : Non-interest income negatively influences the risk of the banking industry

A research conducted by Hidayat et al. (2012) finds that commission activities can intensify the bank risks. As mentioned in Ekanayake and Wanamalie (2017), commission income has no statistically significant relation with risk-adjusted returns in domestic commercial banks. Lepetit et al. (2008) finds that fee-based activities have a positive relation with risk in small banks. Conversely, commission activities (COM) do not significantly affect the risk in large banks. Therefore, this study develops the third hypothesis:

$\mathrm{H}_{3}$ : Commission income positively influences the risk of the banking industry in Indonesia

A study by Meslier, Tacneng, and Tarazi (2013) indicates that higher trading income will reduce the bank risk. Trading income has a positive significant impact on risk. Similarly, Hidayat et al. (2012) show that trading income is significantly positive on risk. Overall, this result indicates that there is a less clear correlation between trading activities and bank risk. As mentioned in Lepetit et al. (2008), small banks benefit from trading activities. Ekanayake and Wanamalie (2017) also find that foreign exchange income is significantly positive on risk. Therefore, this study develops the fourth hypothesis:

$\mathrm{H}_{4}$ : Trading income positively influences the risk of the banking industry in Indonesia

The research of Moudud-Ul-Huq et al. (2018) shows that other non-interest income contributes to the benefit of bank diversification. Moreover, the banks can diversify activities without concerning the volatility of interest income. In addition, other non-interest income appears to be positively and significantly correlated with the risk (Nisar et al., 2018). A research conducted by Ekanayake and Wanamalie (2017) finds that other income is significantly positive on risk. Therefore, this study develops the fifth hypothesis:

$\mathrm{H}_{5}$ : Other non-interest income positively influences the risk of the banking industry in Indonesia

\section{RESEARCH METHOD}

According to De Marco and Mangano (2017), the risk measure is debt leverage because this ratio can be used to calculate how much debt portion a company needed to finance itself while in 
fact the greater the debt, the greater the risk of bankruptcy. Thus, the higher risk will be associated with the higher level of debt. Due to the increase of using debt, there is an implicit cost of debt which increases the cost of equity. Debt to equity ratio is the ratio of total debt to equity. Furthermore, the researcher splits the service activities into four components of Islamic and conventional banks: non-interest income (NII), commission income (COM), trading income (TRAD), and other non-interest income (OTHER). Hence, NII has been defined as a ratio of commission income plus trading income plus other non-interest income to total operating income, in which total operating income is the composition of non-interest income plus interest income minus interest expense (Hidayat et al., 2012; Meslier et al., 2013). COM equals the ratio of commission income to total operating income. TRAD equals the ratio of trading income to total operating income. OTHER equals the ratio of other non-interest income to total operating income.

\section{Data Collection and Sample}

This study uses quantitative method by collecting, processing, and analyzing data from the Financial Services Authority such as Balance Sheet, Profit, and Loss Statements, and Financial Ratio Reports since quarter 22015 to quarter 4 2017. The populations are 116 commercial banks operating in Indonesia, both Islamic and conventional banks. Data taken as samples are obtained by doing purposive sampling method. Then, the researcher chooses the banks based on several assessment criteria including 1) the commercial banks have operated in Indonesia since quarter 22015 to quarter 42017 and issue financial reports regularly to the Financial Services Authority, and 2) the conventional banks have been registered on Indonesia Stock Exchange no later than March 31, 2015, and were recorded until quarter 4 2017. Based on the assessment criteria, the researcher finds 38 conventional banks and 12 Islamic banks from 116 commercial banks. Thus, the total observations involve 550 (50 banks with 11 quarterly observations).

\section{Data Analysis}

In this study, the researcher conducts Structural Equation Modeling (SEM) analysis on multiple groups by dividing samples based on certain characteristics that are determined in advance and are in the process of collecting data. This study provides an example of a risk prediction model that is analyzed by including the criteria for bank types. In this case, there are groups of banks based on conventional principles and Islamic principles. The purpose of the analysis is to find out whether there are similarities in risk between conventional banks and Islamic banks. The full model to measure the relation between service activities and bank risk is as follows:

$$
\begin{aligned}
& R I S K=\alpha_{1} N I+\alpha_{2} C O M+\alpha_{3} T R A D+\alpha_{4} \text { OTHER }+\mathrm{e} \\
& R I S K=\alpha_{1} N F I+\alpha_{2} C O M+\alpha_{3} T R A D+\alpha_{4} O T H E R+\mathrm{e}
\end{aligned}
$$

in which NII is Non-Interest Income (for Conventional bank), NFI is Non-Financing Income (for Islamic bank), COM is Commission Income, TRAD is Trading Income and OTHER is Other NonInterest Income or Other Non-Financing Income.

The relation between variables is tested by using path analysis. All variables in the path analysis, both dependent and independent are variables, can be measured directly (observable). 
The path analysis has several stages that must be passed. First, the researcher specifies the path analysis model. To make an analysis model, the link between one variable and another variable should be based on the existing theoretical foundation. Second, the researcher makes estimation to obtain the path analysis coefficient. Third, the researcher tests the significance of path analysis. Thus, the model to be used is as follows:

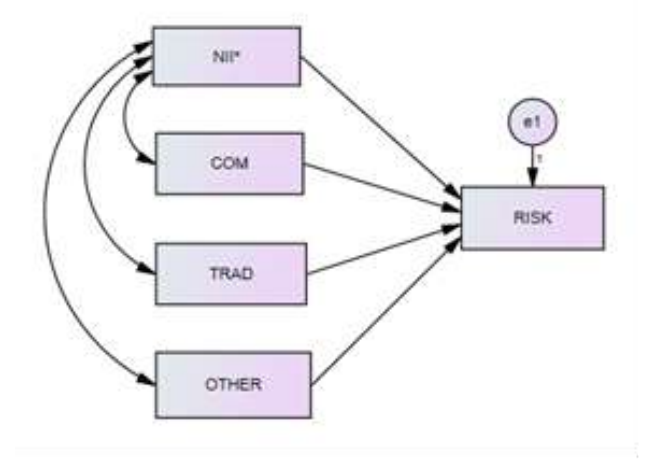

Figure 1. Path analysis model

Based on the model, the researcher will explain the path analysis by taking the path analysis hypothesis. There are five variables in path analysis model which consist of four independent variables (NII/NFI, COM, TRAD, and OTHER) and one dependent variable (RISK). Figure 1 describes the path analysis hypothesis model. From the analysis of the pathway, there are eight path analysis coefficients found, the value from the arrows is either one-way or two-way, and the error term is indicated by the arrow from e1. The risk is influenced by NII / NFI, COM, TRAD, and OTHER.

In the path analysis, the relation between regression and correlation is the path analysis coefficient. The arrows link between NII / NFI (X1) and RISK (Y), COM (X2) and RISK (Y), TRAD $\left(\mathrm{X}_{3}\right)$ and RISK $(\mathrm{Y})$, and also OTHER ( $\left.\mathrm{X}_{4}\right)$ and RISK $(\mathrm{Y})$ that describe the path analysis coefficient (p) of the regression results in the form of equations (1) and (2). Thus, the magnitude of the path analysis coefficient from the regression results are:

$$
p_{y x_{1}}=\alpha_{1}, \quad p_{y x_{2}}=\alpha_{2}, \quad p_{y x_{3}}=\alpha_{3}, \quad p_{y x_{4}}=\alpha_{4}
$$

The path analysis coefficient (p) describes a two-way curved arrow from NII / NFI to COM, from NII / NFI to TRAD, and from NII / NFI to OTHER that the results of the correlation coefficients of the two variables are as follows:

$$
p_{x_{1} x_{2}}=r_{x_{1} x_{2}}, p_{x_{1} x_{3}}=r_{x_{1} x_{3}}, p_{x_{1} x_{4}}=r_{x_{1} x_{4}}
$$

In addition, the researcher tests the significant level of the path analysis coefficient that uses statistical tests as in the multiple regression analysis. If $t$-value is greater than the critical $t$-value or p-value is smaller than the significance level of $\alpha$, then the independent variable is significant. Conversely, if t-count is smaller than the critical t-value or $\mathrm{p}$-value is greater than the significance level of $\alpha$, then the independent variable is not significant. 


\section{RESULTS}

\section{Descriptive Statistics}

Based on the descriptive statistics as set out in Table 1 , five variables are investigated. The researcher investigates the level of risk in banks categorized as low and high levels of Islamic banks, that are PT Bank Maybank Syariah Indonesia (90,46\%), and PT Bank Panin Dubai Syariah (3047.12\%). The lowest non-financing income is on PT Bank Tabungan Pensiunan Nasional Syariah (0.17\%), and the highest non-interest income is on PT Bank Jtrust Indonesia Tbk (89.30\%). The level of commission income obtained by Islamic banks and conventional banks is not optimal with the average value of $8.34 \%$. The highest trading income obtained by PT.

Maybank Syariah Indonesia Bank is $78.89 \%$. The level of other income obtained by Islamic banks and conventional banks is not optimal with the average value of $3.89 \%$. Table 1 shows the descriptive statistics for Islamic and conventional banks.

Table 1. Descriptive statistics

\begin{tabular}{llllll}
\hline & RISK & NII/NFI & COM & TRAD & OTHER \\
\hline Mean & 657.7960 & 23.20313 & 8.340677 & 10.97217 & 3.890287 \\
Median & 598.9542 & 19.16917 & 7.047371 & 5.350272 & 2.607822 \\
Maximum & 3047.119 & 89.29856 & 37.87453 & 78.89145 & 23.72087 \\
Minimum & 90.46331 & 0.166555 & 0.000000 & 0.000000 & 0.000000 \\
Std. Dev. & 281.7773 & 16.71472 & 7.122445 & 15.56827 & 3.989886 \\
Skewness & 1.553773 & 1.371798 & 1.165239 & 2.337860 & 1.763141 \\
Kurtosis & 11.81774 & 4.849292 & 4.659150 & 8.466378 & 7.011308 \\
Jarque-Bera & 2003.130 & 250.8734 & 187.5479 & 1185.792 & 653.7038 \\
Probability & 0.000000 & 0.000000 & 0.00000 & 0.00000 & 0.000000 \\
Sum & 361787.8 & 12761.72 & 4587.372 & 6034.693 & 2139.658 \\
Sum Sq. Dev. & 4358973 & 153380.6 & 27850.34 & 133061.7 & 8739.635 \\
Observations & 550 & 550 & 550 & 550 & 550 \\
\hline
\end{tabular}

\section{Multiple Group Analysis}

This study conducts SEM analysis on multiple groups by dividing the samples based on the characteristics of Islamic bank and conventional bank. 
Table 2. Notes for model (unconstrained)

Computation of degrees of freedom (Unconstrained)

Number of distinct sample moments: $\quad 30$

Number of distinct parameters to be estimated: $\quad 24$

Degrees of freedom $(30-24): \quad 6$

Result (Unconstrained)

Minimum achieved

Chi-square $=47.165$

Degrees of freedom $=6$

Probability level $=.000$

Using multiple group analysis, the probability level is 0.000 which has a value below 0.05 (Hypothesis $\mathrm{H}_{1}$ is accepted). This proves that there are differences between Islamic banks model and conventional banks model.

Table 3. Model fit summary CMIN

\begin{tabular}{lrrrrr}
\hline Model & NPAR & CMIN & DF & P & CMIN/DF \\
\hline Unconstrained & 24 & 47.165 & 6 & .000 & 7.861 \\
Structural weights & & 102.661 & 10 & .000 & 10.266 \\
Structural & & & & & \\
covariance & 13 & 151.311 & 17 & .000 & 8.901 \\
$\begin{array}{l}\text { Structural residuals } \\
\text { Saturated model }\end{array}$ & 12 & 158.579 & 18 & .000 & 8.810 \\
$\begin{array}{l}\text { Independence } \\
\text { Model }\end{array}$ & 30 & .000 & 0 & & \\
\hline
\end{tabular}

In addition to saturated model and independence model, which is a comparison of the standard models on AMOS output, the output includes the results of the four models with the addition of $d f$. numbers from model one to model five, still showing the number of $p$ below 0.05 . The smaller the probability value produced, the influence obtained will be more significant. This indicates that there are differences between Islamic banks model and conventional banks model.

\section{Normality Test}

SEM requires data to be normally distributed or can be considered as normal distribution. The normality test in SEM has two stages; first, the test of normality for each variable, and second, the test of normality for all variables together (multivariate normality). If each variable is individually normal, it does not have a normal distribution which is tested jointly (multivariate). A normal distribution data is marked by skewness value that is close to zero. In Table 1, skewness value indicates that the data can be said to be not normally distributed (RISK: $1.55 \%$, NII/NFI: 1.37\%, COM: $1.17 \%$, TRAD: $2.34 \%$, OTHER: $1.76 \%$ ). The researcher has excluded the data outlier according to the normality test and the outlier detection process.

As a result, the test of data normality and outliers are in the variable summary section which is divided into the Assessment of Normality and the Furthest Observations from the Centroid. 
Thus, the total observations involve 423 banks which consist of 80 observations of Islamic banks and 343 observations of conventional banks.

Table 4. Assessment of normality (Islamic banks)

\begin{tabular}{lrrrrrr}
\hline Variable & Min & \multicolumn{1}{c}{ Max } & Skew & \multicolumn{1}{c}{ c.r. } & Kurtosis & \multicolumn{1}{c}{ c.r. } \\
\hline OTHER & -.928 & $1 ., 375$ & .585 & 2.138 & -.485 & -.885 \\
TRAD & -.745 & 1.546 & .268 & .979 & -.827 & -1.509 \\
COM & .000 & 21.866 & .731 & 2.670 & -.271 & -.495 \\
NFI & .167 & 45.906 & .727 & 2.654 & -.507 & -.926 \\
RISK & 2.405 & 3.179 & -.502 & -1.834 & -.912 & -1.666 \\
Multivariate & & & & & -2.059 & -1.101 \\
\hline
\end{tabular}

Table 5. Assessment of normality (Conventional banks)

\begin{tabular}{lcccccc}
\hline \multicolumn{1}{c}{ Variable } & Min & Max & Skew & c.r. & Kurtosis & c.r. \\
\hline OTHER & -.653 & 1.335 & -.279 & -2.109 & -.917 & -3.466 \\
TRAD & -1.091 & 1.448 & -.764 & -5.778 & -.056 & -.212 \\
COM & .000 & 20.505 & .272 & 2.060 & -1.127 & -4.259 \\
NII & 2.113 & 43.804 & .154 & 1.161 & -.667 & -2.522 \\
RISK & 2.415 & 3.151 & -.134 & -1.012 & -.229 & -.864 \\
Multivariate & & & & & -.249 & -.276 \\
\hline
\end{tabular}

Regarding the assessment of normality in Table 4, the result shows that those data have a normal distribution. The multivariate number $(-1,101)<2.58$, and the variables of OTHER, TRAD, COM, NFI, and RISK have cr kurtosis (-0,885; -1.509; -0.495; -0.926; -1.666), which is far from the limit of 2.58 at a significance level $=1 \%$, and $\mathrm{z}= \pm 2.58)$. The results in Table 5 show that the multivariate has a normal distribution because the multivariate number is $(-0.276)<2.58$. Furthermore, the variables of OTHER, TRAD, COM, NFI, and RISK have cr kurtosis (-3.466; $0.212 ;-4.259 ;-2.522 ;-0.864$ ), whose value is far from the limit of 2.58 . Although the variables of OTHER and COM have cr kurtosis below -2.58, both of them actually have cr skewness (OTHER: -2.109 and COM: 2.06o) between -2.58 and +2.58 . Generally, the distribution of the data used in this model can be considered as a normal distribution.

Table 6. Observations farthest from the centroid (Mahalanobis distance)

\begin{tabular}{crcc}
\hline Observation number & $\begin{array}{r}\text { Mahalanobis d- } \\
\text { squared }\end{array}$ & p1 & p2 \\
\hline 59 & 14.152 & .015 & .694 \\
57 & 11.030 & .051 & .918 \\
7 & 10.577 & .060 & .869 \\
54 & 9.581 & .088 & .930 \\
58 & 9.457 & .092 & .871 \\
25 & 9.447 & .093 & .761 \\
67 & 9.284 & .098 & .682 \\
8 & 9.128 & .104 & .601 \\
\hline
\end{tabular}


Table 7. Observations farthest from the centroid (Mahalanobis distance)

\begin{tabular}{rrrr}
\hline Observation number & $\begin{array}{r}\text { Mahalanobis d- } \\
\text { squared }\end{array}$ & p1 & p2 \\
\hline 322 & 23.995 & .000 & .072 \\
316 & 19.856 & .001 & .077 \\
98 & 17.866 & .003 & .093 \\
96 & 16.132 & .006 & .184 \\
214 & 15.356 & .009 & .196 \\
92 & 15.095 & .010 & .131 \\
323 & 14.990 & .010 & .070 \\
340 & 13.704 & .018 & .260 \\
\hline
\end{tabular}

Regarding the Furthest Observations from the Centroid in Table 4 and 5 (shown in parts), the result shows that there are no p2 numbers worth below 0.05 . This proves the absence of data considered outliers.

\section{SEM with Path Analysis}

In practice, SEM analysis tests the model which has the fit model before entering into path analysis.

Table 8. Goodness fit criteria

\begin{tabular}{lrrrr}
\hline Model & RMR & GFI & AGFI & PGFI \\
\hline Unconstrained & 1.874 & .961 & .805 & .192 \\
Structural weights & 1.877 & .927 & .781 & .309 \\
Structural covariance & 8.216 & .876 & .781 & .496 \\
Structural residuals & 8.216 & .864 & .773 & .518 \\
Saturated model & .000 & 1.000 & & \\
Independence model & 8.113 & .679 & .518 & .452 \\
\hline
\end{tabular}

Table 9. Baseline comparisons

\begin{tabular}{lrrrrr}
\hline Model & $\begin{array}{r}\text { NFI } \\
\text { Delta1 }\end{array}$ & $\begin{array}{r}\text { RFI } \\
\text { rho1 }\end{array}$ & $\begin{array}{r}\text { IFI } \\
\text { Delta2 }\end{array}$ & $\begin{array}{r}\text { TLI } \\
\text { rho2 }\end{array}$ & CFI \\
\hline Unconstrained & .949 & .830 & .955 & .848 & .954 \\
Structural weights & .889 & .778 & .899 & .795 & .897 \\
Structural covariance & .836 & .807 & .852 & .825 & .851 \\
Structural residuals & .828 & .809 & .845 & 827 & .844 \\
Saturated model & 1.000 & & 1.000 & & 1.000 \\
Independence model & .000 & .000 & .000 & .000 & .000 \\
\hline
\end{tabular}


Table 10. RMSEA

\begin{tabular}{lrrrr}
\hline Model & RMSEA & LO 90 & HI 90 & PCLOSE \\
\hline Unconstrained & .128 & .095 & .163 & .000 \\
Structural weigts & .148 & .123 & .175 & .000 \\
Structural covariance & .137 & .117 & .157 & .000 \\
Structural residuals & .136 & .117 & .156 & .000 \\
Independence model & .327 & .310 & .346 & .000 \\
\hline
\end{tabular}

Table 8, 9, and 10 of GFI (0.961) and AGFI (0.805) are seen to be above o.9. Similarly, NFI (o.949) and IFI (0.955) are also above 0.9. RMSEA is still above 0.09. The test result indicates that the model can be said as a good fit.

Table 11. The result of hypotheses testing

\begin{tabular}{|c|c|c|c|c|c|}
\hline Hypothesis & Path & $\alpha$ & C.R. & $\mathrm{P}$ & Note \\
\hline \multicolumn{2}{|c|}{ RISK<--- NFI } & -0.010 & -2.885 & 0.004 & Accepted \\
\hline & Ris'SK<--- NII ${ }^{\mathrm{b}}$ & 0.003 & 1.254 & 0.210 & Rejected \\
\hline \multirow{2}{*}{$\mathrm{H}_{3}$} & RISK $<---$ COM $^{a}$ & 0.039 & 8.130 & $* * * *$ & Accepted \\
\hline & RISK<--- $\mathrm{COM}^{\mathrm{b}}$ & -0.001 & -0.218 & 0.827 & Rejected \\
\hline \multicolumn{2}{|c|}{ RISK<--- TRAD ${ }^{\mathrm{a}}$} & 0.141 & 2.427 & 0.015 & Accepted \\
\hline & RISK<--- TRAD ${ }^{\mathrm{b}}$ & -0.006 & -0.209 & 0.835 & Rejected \\
\hline \multirow{2}{*}{$\mathrm{H}_{5}$} & RISK<--- OTHER ${ }^{\mathrm{a}}$ & 0.006 & 0.148 & 0.883 & Rejected \\
\hline & RISK<--- OTHER ${ }^{\mathrm{b}}$ & 0.004 & 0.175 & 0.861 & Rejected \\
\hline
\end{tabular}

a.Islamic banks

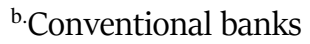

$$
\begin{aligned}
& R I S K=-0.010 N F I+0.039 C O M+0.141 T R A D+0.006 O T H E R+\mathrm{e} \quad(1 \mathrm{a}) \\
& R I S K=0.003 N I-0.001 C O M-0.006 T R A D+0.004 O T H E R+\mathrm{e} \quad(1 \mathrm{~b})
\end{aligned}
$$

The path analysis coefficient (p) is illustrated by arrows from NFI to RISK ( $\alpha_{1}=-0.010$ ), from COM to RISK $\left(\alpha_{2}=0.039\right)$, from TRAD to RISK $\left(\alpha_{3}=0.141\right)$ and from OTHER to RISK ( $\left.\alpha_{4}=0.006\right)$. The path analysis coefficient (p) depicts a two-way curved arrow from NFI to COM (0.429), from NFI to TRAD (0.716), and from NFI to OTHER (0.401) which are the results of the correlation coefficients of two variables.

As can be seen in Table 11 (Model 1a), non-financing income (NFI) indicates a negative significant impact on bank risk. Commission income (COM) indicates a positive significant impact on bank risk. Trading income (TRAD) indicates a positive significant impact on bank risk. Other non-financing income (OTHER) indicates a positive impact on bank risk.

The path analysis coefficient (p) is illustrated by arrows from NII to RISK ( $\left.\alpha_{1}=0.003\right)$, from COM to RISK $\left(\alpha_{2}=-0.001\right)$, from TRAD to RISK $\left(\alpha_{3}=-0.006\right)$ and from OTHER to RISK $\left(\alpha_{4}=0.004\right)$. The path analysis coefficient (p) depicts a two-way curved arrow from NII to COM (0.597), from NII to TRAD (0.612), and from NII to OTHER (0.329), which are the results of the correlation coefficients of two variables.

Table 11 (Model 1b) illustrates the estimation results in conventional banks. Non-interest income (NII) indicates a positive impact on bank risk. Commission income (COM) indicates a negative impact on bank risk. Trading income (TRAD) indicates a negative impact on bank risk. 
Other non-interest income (OTHER) indicates a positive impact on bank risk. Thus, the result is not found in conventional banks.

\section{The Modification of SEM Model}

Because the value of RMSEA is 0.128 (the criteria of RMSEA value is smaller than o.o8), the researcher tests the modification of SEM model. The modification of SEM model is only to prove whether the model that has been made can work well.

Table 12. Modification Indices (Islamic \& Conventional banks - Unconstrained)

Modification Indices (Islamic \& Conventional - Unconstrained)

Covariance: (Islamic \& Conventional - Unconstrained)

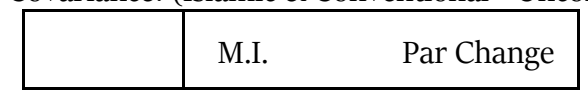

Variances: (Islamic \& Conventional - Unconstrained)

\begin{tabular}{|l|l|}
\hline & M.I. $\quad$ Par Change \\
\hline
\end{tabular}

Regression Weights: (Islamic \& Conventional - Unconstrained)

\begin{tabular}{|l|ll|}
\hline & M.I. $\quad$ Par Change \\
\hline
\end{tabular}

In the Modification Indices section (Table 12), the results do not display any numbers. This shows that the subsequent modification process does not produce alternative decreases of ChiSquare for more than 4 . Thus, the modification process can be stopped.

\section{DISCUSSION}

\section{The Comparison of Service Activities in Islamic Banks and Conventional Banks}

The services activities of Islamic banks are more various than conventional banks. This study is supported by Beck, Kunt, and Merrouche (2013) that conventional banks have lower service activities compared to Islamic banks. A research from Faye, Triki, and Kangoye (2013) also finds that in North African countries, Islamic banks have more diversified activities than conventional banks. Moreover, a research from Hardianto and Wulandari (2016) indicates that Islamic banks have limitations in lending activities because they lend money directly to customers by asking for return as usury. Therefore, Islamic banks develop financial services to look for other income alternatives in order to mitigate risk and improve banks performance.

\section{The Comparison of Risk in Islamic Banks and Conventional Banks}

The risk of Islamic banks is more stable than in conventional banks. Islamic banks do not adjust interest rates which do not require the higher capital in service activities (Karanja, 2012). However, the risk of conventional banks becomes volatile because there is a necessity to pay the interest as a fixed cost. The interest cost is used to pay the long-term debt as a source of funds for conventional banks. Debt has disadvantage such as difficulty caused by debt obligations. This is 
in line with the research conducted by De Marco and Mangano (2017) which says that high-risk countries are associated with higher debt level and decreased equity of capital injections.

\section{The Impact of Non-Financing Income (Non-Interest Income) on Risk}

Non-financing income has shown a negative significant impact on risk. The higher non-financing income can reduce the bank risk so that service activities must be maximized. This study is in line with findings from past studies (Grassa, 2012; Hamdi et al., 2017; Hidayat et al., 2012; MoududUl-Huq et al., 2018; Nguyen et al., 2015). However, this study is not in line with a research conducted by other scholars (Ekanayake \& Wanamalie, 2017; Le, 2016; Nguyen, Perera, \& Skully, 2016; Nisar et al., 2018). Compared to conventional banks, the effect of non-interest income on risk is not statistically significant but beta values indicate that the effect of non-interest income is positive on risk. Although conventional banks obtain higher non-interest income than Islamic banks, the cost dominates the benefit in service activities. This study is in line with a research conducted by Trivedi (2015), non-interest income shows a negative impact on risk. However, this study is not in line with previous studies (Ekanayake \& Wanamalie, 2017; Hamdi et al., 2017; Hidayat et al., 2012; Le, 2016; Lepetit et al., 2008; Meslier et al., 2013; Moudud-Ul-Huq et al., 2018; Nguyen et al., 2016; Nguyen et al., 2015; Nisar et al., 2018).

\section{The Impact of Commission Income on Risk}

Commission Income shows a positive significant impact on risk. Islamic banks are revealed to have higher risk when commission income increases. The increased risk which is associated with commission activity can contribute the finding that income volatility from this activity is relatively high. This study is in line with previous studies (Hidayat et al., 2012; Lepetit et al., 2008). However, this study is not in line with the researches conducted by Ekanayake and Wanamalie (2017) and Nisar et al. (2018). Compared to conventional banks, the effect of commission income on risk is not statistically significant but beta values indicate that the effect of commission income is negative on risk. This study supports the researches conducted in the past studies (Ekanayake \& Wanamalie, 2017; Meslier et al., 2013) that commission income has no significant impact on bank risk. However, this study is not supported by Hidayat et al. (2012) and Lepetit et al. (2008).

\section{The Impact of Trading Income on Risk}

Trading income shows a positive significant impact on bank risk. Islamic banks have relatively lower income in trading activities than conventional banks because they are limited to money market products due to Islamic principles. This study is in line with past studies (Ekanayake \& Wanamalie, 2017; Hidayat et al., 2012; Meslier et al., 2013). Compared to conventional banks, the effect of trading income on risk is not statistically significant but beta values indicate that the effect of trading income is negative on risk. Conventional banks are more dependent on marketbased risk indicators which are seen from higher trading share. Conversely, Islamic banks are associated with the risk of default. This study is in line with Lepetit et al. (2008) which says that trading income does not show a positive impact on risk. However, this study is not supported by other scholars (Ekanayake \& Wanamalie, 2017; Hidayat et al., 2012; Meslier et al., 2013). 


\section{The Impact of Other Non-Financing Income (Other Non-Interest Income) on Risk}

Other Non-Financing Income is not statistically significant but beta values indicate that the effect of Other Non-Financing Income is positive on risk. This study is not in line with Nisar et al. (2018) which finds that other non-interest income shows a positive and highly significant impact on bank risk. A research by Ekanayake and Wanamalie (2017) shows that other income has significant positive impact on risk. Subsequent research by Meslier et al. (2013) shows that the OTHER is positively related to risk. On the other hand, the increase of other non-interest income in conventional banks has a positive effect direction, although the result is not statistically significant. This study is not in line with the research conducted by other empirical studies (Ekanayake \& Wanamalie, 2017; Meslier et al., 2013; Nisar et al., 2018).

\section{MANAGERIAL IMPLICATION}

This study discusses about the use of correlated path analysis model to predict the service activities and risk in Structural Equation Modeling (SEM). Islamic banks have evidence that risk is reduced when service activity is represented by non-financing income. There is a strong relation between commission income and risk. The strong relation between trading income and risk is found in Islamic banks. The strong relation between other non-financing income and risk is not found in Islamic banks but the direction of other non-financing income is positive on risk. Regarding the risk measure, there is an interesting evidence to apply debt to equity ratio in conventional banks. The strong relation to predict the risk is not found in non-interest income, commission income, trading income, and other non-interest income. The evidence can obviously help the researcher to understand this model.

The heads of Islamic banks are supposed to implement a retail marketing strategy on a small scale: 1) offering standard financial service products that must be owned by Islamic banks especially savings, deposits, demand deposits, and micro-financing, 2) determining the price of products and services related to market prices because retail businesses are not too delicate to margin level or interest rates, 3) conducting relatively large promotions through words or dakwah program, 4) offering a variety of services including domestic and foreign money transfers, fundraising, safe deposit box, letters of credit (L/C sharia schemes) and sharia credit cards, 5) determining service distribution or marketing outlets with branch offices, KCPs, units, and others such as ATM, CDM, internet banking, phone banking, mobile banking, mobile branches and through third-party outlets as post offices, 6) implementing a retail business pattern that uses more personal approaches (face to face service with customers that must be attractive and friendly), 7) providing massive services with a relatively short service level of agreement, 8) conducting active service activities in payment traffic such as the issuance of checks/giro and clearing, and 9) providing services related to leases made by customers. However, the heads of conventional banks are expected to implement a commercial marketing strategy on a large scale. In conventional banks, the income obtained by the service activities which are non-interest income, commission income, trading income, and other non-interest income is relatively higher than in Islamic banks, but the incurred cost is also higher. The following steps are needed: 1) offering complex financial services as well as a letter of credit, trust service, cash management, supply chain management, hedging, syndicated financing, and others, 2) conducting promotions 
that are relatively not too large, 3) implementing a commercial business pattern that uses the $\mathrm{C}_{2} \mathrm{C}$ (Corporate to Corporate) approach, and 4) provide detail and specific services.

\section{LIMITATION AND FUTURE RESEARCH}

The study investigates the risk prediction on the service activity shown by Indonesian banking industry in the period of 2015 - 2017. This study shows clear evidence that risk is reduced when the Islamic banks diversify their service activity, in addition to non-financing income. Commission income and trading income show a significant positive impact on bank risk. This effect is not found in other non-financing income. However, the conventional banks show that diversified activities assist to the increase of income volatility. The service activities are not related to bank risk for non-interest income, commission income, trading income, and other non-interest income. This conclusion recommends the strategies to control the risk. Islamic banks increase service products that develop the financial products to enhance other income alternatives in order to reduce bank risk. It also emphasizes the importance of expanding new service activities. Islamic banks do not adjust interest rates, which is based on Islamic principle for expanding the service activity. Conversely, conventional banks provide capital to pay interest as a fixed expense. Conventional banks need to reduce the high cost of depositors, which are savings, demand deposits, time deposits, and also interest costs of long-term debt that are used as a source of fund.

Specifically, this study has examined that the service activity and bank risk have a direct effect on the path analysis model. The relation between service activity and bank risk should be conducted to understand the debt ratio of Islamic banks and conventional banks. When the researcher finds the service activities do not affect risk in conventional banks, the analysis should be taken into variables, not only other risk measurements but also the control variables due to their close interactions.

Regarding future studies, this paper can also be extended in several interesting. For example, the next researchers can explore the model specification of service activities that are related to bank risk in path analysis model. Moreover, the use of path analysis can capture the mediation model and the correlated model to show direct or indirect effect.

\section{REFERENCES}

Alfarisi, M. F. (2015). Impact of Financial Crisis on Non-Traditional Income: Islamic Banks Vis a Vis Conventional Banks. Journal of Islamic Finance, 4(1), 031-038. doi: 10.12816/0024799.

Beck, T., Kunt, A. D., \& Merrouche, O. (2013). Islamic vs conventional banking: Business model, efficiency and stability. Journal of Banking \& Finance, 37, 433-447. doi: 10.1016/j.jbankfin.2012.09.016.

De Marco, A., \& Mangano, G. (2013). Risk and value in privately finance healthcare projects. Journal of Construction Engineering and Management, 918-926.

De Marco, A., \& Mangano, G. (2017). Risk factors influencing the debt leverage of project financing initiatives in the energy industry. International Journal of Energy Sector Management, 17506220.

Ekanayake, N., \& Wanamalie. (2017). Income Diversification and Bank Risk-Return Trade-Off: Evidence from an Emerging Economy. Asian Economic and Financial Review, 7(7), 644-655. doi: 10.18488/journal.aefr.2017.77.644.655. 
Elsas, R., Hackethal, A., \& Holzhauser, M. (2010). The Anatomy of Bank Diversification. Journal of Banking \& Finance, 1274-1287.

Faye, I., Triki, T., \& Kangoye, T. (2013). The Islamic Finance Promises: Evidence from Africa. Review of Development Finance, 136-151.

Grassa, R. (2012). Islamic Banks Income Structure and Risk : Evidence from GCC Countries. Accounting Research Journal, 25(3), 227-241. doi: 10.1108/10309611211290185

Hamdi, H., Hakimi, A., \& Zaghdoudi, K. (2017). Diversification, bank performance and risk: have Tunisian banks adopted the new business model? Financial Innovation, 3(22), 1-25. doi: 10.1186/s40854-017-0069-6

Hardianto, D. S., \& Wulandari, P. (2016). Islamic Bank Vs Conventional Bank : Intermediation, Fee Based Service Activity and Efficiency. International Journal of Islamic and Middle Eastern Finance and Management, 9(2), 1-18. doi: 10.1108/IMEFM-01-2015-0003

Hidayat, W. Y., Kakinaka, M., \& Miyamoto, H. (2012). Bank Risk and Non Interest Income Activities in the Indonesian Banking Industry. Economics \& Management Series, o3, 1-25.

Karanja, N. e. (2012). The Relationship Between Non Interest Income and Financial Performance of Commercial Banks in Kenya. -, 1-67.

Landskroner, Y., Ruthenberg, D., \& Zaken, D. (2005). Diversification and Performance in Banking: The Israeli Case. Journal of Financial Services Research, 27-49.

Le, T. (2016). The effect of income diversification on bank risk: Evidence from Vietnam. SSRN Electronic Journal, 1-2.

Lepetit, L., Nys., E., Rous, P., \& Tarazi, A. (2008). Bank Income Structure and Risk : An Empirical Analysis of European Banks. Journal of Banking and Finance, 32, 1452-1467. doi: 10.1016/j.jbankfin.2007.12.002

Meslier, C., Tacneng, R., \& Tarazi, A. (2013). Bank Diversification, Risk and Profitability in an Emerging Economy with Regulatory Asset Structure Constraints : Evidence from the Philippines. Archives Ouvertes, 1-55.

Molyneux, P., \& Yip, J. (2013). Income Diversification and Performance of Islamic Banks. Journal of Financial Management, Markets and Institutions, 1(1), 47-66. doi: 10.12831/73632

Moudud-Ul-Huq, S., Ashraf, B. N., Gupta, A. D., \& Zheng, C. (2018). Does bank diversification heterogeneously affect performance and risk-taking in ASEAN emerging economies? Research in International Business and Finance, 1-22. doi: 10.1016/j.ribaf.2018.04.007

Ng, S. T., Xie, J., \& Kumaraswamy, M. M. (2010). Simulating the effect of risks on equity return for concession-based public-private partnership projects. Engineering, Construction and Architectural Management, 352-368.

Nguyen, M., Perera, S., \& Skully, M. (2016). Bank market power, ownership, regional presence and revenue diversification: Evidence from Africa Emerging Markets Review, 1-27. doi: 10.1016/j.ememar.2016.03.001

Nguyen, T. C., Vo, D. V., \& Nguyen, V. C. (2015). Risk and Income Diversification in the Vietnamese Banking System. Journal of Applied Finance \& Banking, 5(1), 99-115.

Nisar, S., Peng, K., Wang, S., \& Ashraf, B. N. (2018). The Impact of Revenue Diversification on Bank Profitability and Stability: Empirical Evidence from South Asian Countries. International Journal of Financial Studies, 6(40), 1-25. doi: 10.3390/ijfs6020040

Suhartanto, D., Muflih, M., Setiawan, \& Hadiati, N. (2018). Loyalty Intention towards Islamic Bank: The Role of Religiosity, Image, and Trust. International Journal of Economics and Management, 12(1), 137-151.

Trivedi, S. R. (2015). Banking Innovations and New Income Streams : Impact on Banks Performance. The Journal for Decision Makers, 4o(1), 28-41. doi: 10.1177/0256090915573616 